\title{
Life Cycle-Based Host Range Analysis for Tomato Spotted Wilt Virus in Korea
}

\author{
Eui-Joon Kil $\mathbb{D}^{1}{ }^{1}$, Young-Jae Chung ${ }^{2}$, Hong-Soo Choi ${ }^{3}$, Sukchan Lee $\mathbb{D}^{1 *}$, and Chang-Seok Kim ${ }^{4 *}$ \\ ${ }^{1}$ College of Biotechnology and Bioengineering, Sungkyunkwan University, Suwon 16419, Korea \\ ${ }^{2}$ Department of Life Science and Biotechnology, Shingyeong University, Hwaseong 18274, Korea \\ ${ }^{3}$ Crop Protection Division, National Academy of Agricultural Science, Rural Development Administration, Wanju \\ 55365, Korea \\ ${ }^{4}$ Highland Agriculture Research Institute, National Institute of Crop Science, Rural Development Administration, \\ Pyeongchang 25342, Korea
}

(Received on December 5, 2019; Revised on December 9, 2019; Accepted on December 11, 2019)

Tomato spotted wilt virus (TSWV) is one of the plant viruses transmitted by thrips and causes severe economic damage to various crops. From 2008 to 2011, to identify natural host species of TSWV in South Korea, weeds and crops were collected from 5 regions (Seosan, Yesan, Yeonggwang, Naju, and Suncheon) where TSWV occurred and were identified as 1,104 samples that belong to 144 species from 40 families. According to reverse transcription-polymerase chain reaction, TSWV was detected from 73 samples from 23 crop species, 5 of which belonged to family Solanaceae. Additionally, 42 weed species were confirmed as natural hosts of TSWV with three different life cycles, indicating that these weed species could play an important role as virus reservoirs during no cultivation periods of crops. This study provides up-to-date comprehensive information for TSWV natural hosts in South Korea.

\footnotetext{
*Co-corresponding authors.

Sukchan Lee

Phone) +82-31-290-7866, FAX) +82-31-290-7892

E-mail) cell4u@skku.edu

Chang-Seok Kim

Phone) +82-33-330-1935, FAX) +82-33-330-1519

E-mail) rdacskim@korea.kr

ORCID
}

Eui-Joon Kil

https://orcid.org/0000-0002-7256-3879

Sukchan Lee

https://orcid.org/0000-0002-9964-0176

(c) This is an Open Access article distributed under the terms of the Creative Commons Attribution Non-Commercial License (http:// creativecommons.org/licenses/by-nc/4.0) which permits unrestricted noncommercial use, distribution, and reproduction in any medium, provided the original work is properly cited.

Articles can be freely viewed online at www.ppjonline.org.
Keywords : reservoir, Tomato spotted wilt virus (TSWV), Tospovirus

Handling Editor : Ju-Yeon Yoon

Tomato spotted wilt virus (TSWV) is a member of the genus Orthotospovirus in the family Tospoviridae (Maes et al., 2018). Their genome consists of three negative or ambisense, single-stranded RNA species designated as S ( $2.9 \mathrm{~kb}), \mathrm{M}(4.8 \mathrm{~kb})$, and L (8.9 kb) with partially complementary terminal sequences (Adkins, 2000). Their pleomorphic particles are 80-120 $\mathrm{nm}$ in diameter with surface projections composed of two viral glycoproteins G1 and G2 (Adkins, 2000; Pappu, 2008). The first report of the disease 'spotted wilt of tomato' was described by Charles Brittlebank, an Australian phytopathologist, in 1919 (Best, 1968; Brittlebank, 1919). In 1930, Samuel characterized this pathogen as a virus and named it TSWV (Samuel, 1930). According to the first report of International Committee on Taxonomy of Viruses (ICTV), TSWV was the sole member of 'Tomato spotted wilt virus group' (Fenner, 1976). After the early 1990s, because several similar viruses to TSWV were identified and characterized, the genus Tospovirus was created and changed to the family Tospoviridae according to the most recently proposed classification (Maes et al., 2018; Murphy et al., 1995).

TSWV-infected plants show typical symptoms such as yellowing; mottling; chlorotic, ring spots of leaves and fruits; and stunting, inducing significant crop losses. Expression of these symptoms can vary depending on strain (or isolate) of the infected TSWV, plant species, crop cultivars and growth stage of the infected plants and environmental conditions of the infected plants (Adkins, 2000; German et 
al., 1992; Riley et al., 2011; Scholthof et al., 2011). TSWV is transmitted by approximately 10 species of thrips including the western flower thrips (Frankliniella occidentalis) (Riley et al., 2011; Sundaraj et al., 2014). TSWV occurrences have economic importance in cultivation of many crops because of the significantly decreased crop yields of the infected plants. In addition, TSWV disease spread rapidly to new healthy plants since viruliferous western flower thrips ( $F$. occidentalis) are difficult for population management using chemical insecticides or natural organic compounds (Adkins, 2000; Jiang et al., 2017). Mechanical transmission of TSWV is also possibly transmitted from sap of naturally infected plants (Parrella et al., 2003).

TSWV is one of the plants viruses with the largest host range (Parrella et al., 2003). Over 1,000 plant species in over 85 families including many cultivated crops such as peanut (Arachis hypogaea), pepper (Capsicum annuum), potato (Solanum tuberosum), spinach (Spinacia oleracea), tobacco (Nicotiana tabacum), and tomato (Solanum lycopersicum) are reported TSWV natural hosts (Brittlebank, 1919; Cho et al., 1987; Costa, 1941; German et al., 1992; Parrella et al., 2003; Sakimura, 1940; Sherwood et al., 2009; Smith, 1931). In addition to economic crops, various weeds are also known natural hosts of TSWV and can be act as reservoirs for viral spread to other susceptible crops (Chatzivassiliou et al., 2001; Cho et al., 1986; Parrella et al., 2003).

TSWV is one of the most important plant viruses, reported in about 100 countries on all continents (OEPP/EPPO, 1999). In South Korea, TSWV was first reported on sweet pepper (paprika) from Yesan in 2004 (Kim et al., 2004) and spread nationwide. Mainly, TSWV occurrences in Korea have been reported continuously from tomato, pepper, and potato (Yoon et al., 2017). TSWV infection was also found in soybean (Glycine max), Brugmansia suaveolens, Eustoma grandiflorum, Hoya carnosa, Humulus japonicas, and Peperomia obtusifolia in Korea (Choi et al., 2014; Kim et al., 2018; Yoon et al., 2017, 2018a, 2019). Many hot pepper farms in Korea have suffered from TSWV.

Previously, the host range investigations of TSWV in various plants including weeds were reported (Cho et al., 1986, 1987; Parrella et al., 2003). In recent years, however, report from large-scale investigations have not been issued. In this study, to update lists, we examined crop and weed hosts of TSWV in Korea.

\section{Materials and Methods}

Sample collection. From 2008 to 2011, to investigate the

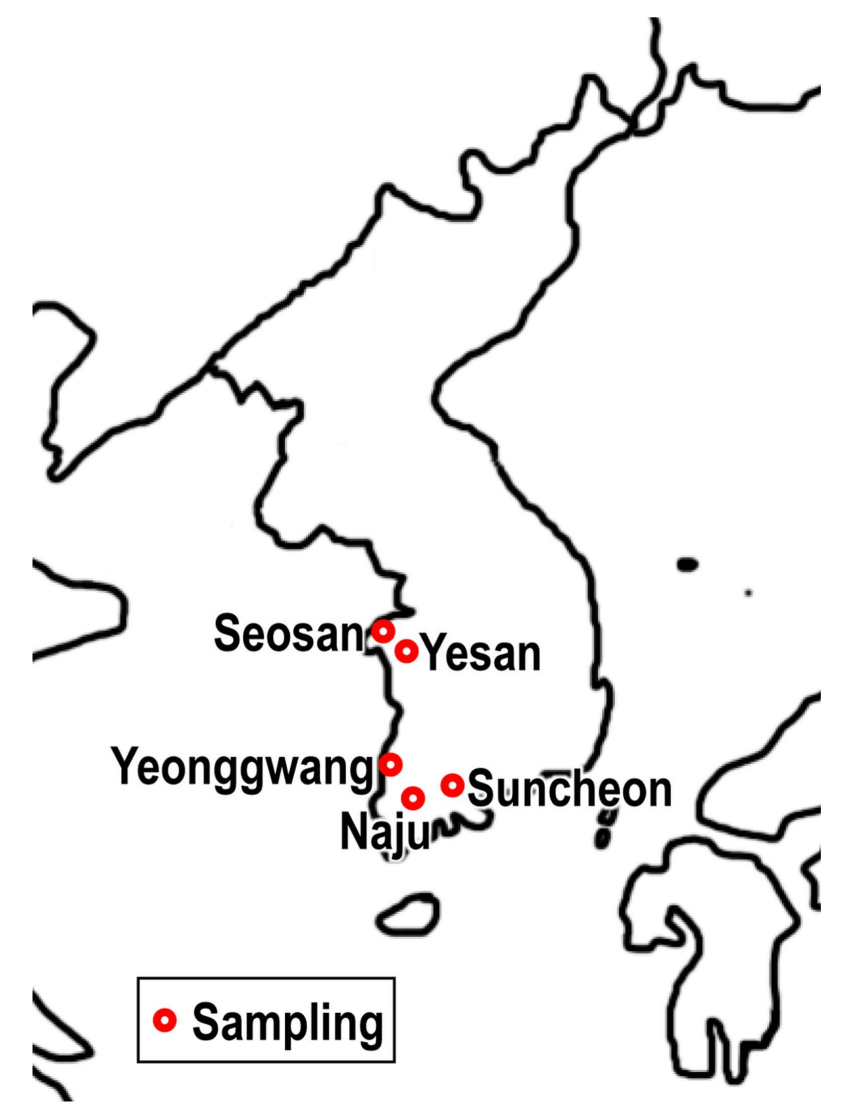

Fig. 1. Korean collection locations of crop and weed samples in this study.

influence of host plants on the spread of TSWV, samples of crops and weeds were collected. To investigate natural host plants from plants with different life cycles, plant samples were collected in the winter (November to February), spring (March to May), and summer (June to October). Sampling was conducted in five areas where occurrence of TSWV has been reported continuously (Suncheon, Naju, Yeonggwang, Seosan, and Yesan) in South Korea (Fig. 1). Sample collection points were inside and outside of nonheated greenhouses that had been used as nurseries for hot pepper seedlings, and other crop cultivating greenhouses or open fields around hot pepper cultivating greenhouses or open fields.

RNA isolation and virus diagnosis. Total RNA was extracted from collected samples with easy-spin Total RNA Extraction Kit (Intron Biotechnology, Seongnam, Korea) according to the manufacturer's manual. TSWV infection was confirmed by RT-PCR with AMV Reverse Transcriptase (for cDNA synthesis, Promega, Madison, WI, USA), GoTaq DNA Polymerase (for PCR, Promega), and 
Table 1. Numbers of tested crops and weeds for Tomato spotted wilt virus (TSWV) detection in this study

\begin{tabular}{|c|c|c|c|}
\hline Family & $\begin{array}{l}\text { No. of tested } \\
\text { species }\end{array}$ & $\begin{array}{l}\text { No. of detected } \\
\text { species }\end{array}$ & $\begin{array}{c}\text { No. of tested } \\
\text { samples }\end{array}$ \\
\hline Asteraceae & 29 & 9 & 300 \\
\hline Amaranthaceae & 5 & 2 & 103 \\
\hline Apiaceae & 2 & 1 & 13 \\
\hline Asclepiadaceae & 1 & 1 & 4 \\
\hline Boraginaceae & 1 & 0 & 1 \\
\hline Brassicaceae & 9 & 8 & 80 \\
\hline Campanulaceae & 1 & 1 & 4 \\
\hline Cannabaceae & 1 & 0 & 3 \\
\hline Caprifoliaceae & 1 & 0 & 1 \\
\hline Caryophyllaceae & 6 & 6 & 104 \\
\hline Chenopodiaceae & 4 & 2 & 46 \\
\hline Commelinoideae & 1 & 1 & 18 \\
\hline Convolvulaceae & 3 & 2 & 42 \\
\hline Crassulaceae & 1 & 1 & 1 \\
\hline Cucurbitaceae & 4 & 3 & 18 \\
\hline Euphorbiaceae & 2 & 1 & 18 \\
\hline Fabaceae & 12 & 7 & 36 \\
\hline Fagaceae & 1 & 0 & 1 \\
\hline Lamiaceae & 4 & 2 & 9 \\
\hline Liliaceae & 6 & 2 & 38 \\
\hline Malvaceae & 2 & 2 & 8 \\
\hline Meliaceae & 1 & 0 & 7 \\
\hline Menispermaceae & 1 & 0 & 1 \\
\hline Moraceae & 3 & 1 & 10 \\
\hline Oleaceae & 1 & 1 & 3 \\
\hline Oxalidaceae & 3 & 0 & 4 \\
\hline Phytolaccaceae & 1 & 1 & 60 \\
\hline Poaceae & 8 & 1 & 56 \\
\hline Polygonaceae & 4 & 1 & 11 \\
\hline Portulacaceae & 1 & 0 & 4 \\
\hline Pteridaceae & 1 & 0 & 1 \\
\hline Ranunculaceae & 2 & 0 & 2 \\
\hline Rosaceae & 3 & 0 & 9 \\
\hline Rubiaceae & 2 & 2 & 16 \\
\hline Rutaceae & 1 & 0 & 2 \\
\hline Scrophulariaceae & 3 & 1 & 18 \\
\hline Solanaceae & 8 & 6 & 37 \\
\hline Ulmaceae & 1 & 0 & 3 \\
\hline Urticaceae & 2 & 0 & 6 \\
\hline \multirow[t]{2}{*}{ Vitaceae } & 2 & 0 & 6 \\
\hline & 144 & 65 & 1,104 \\
\hline
\end{tabular}

a TSWV-specific primer set (TSWV-6F, 5'-GAGATTCTCAGAATTCCCAGT-3'; TSWV-6R, 5'-AGAGCAATCGTGTCAATTTTATTC-3'), as described in a previous study (Tables 1-3) (Ko et al., 2013).
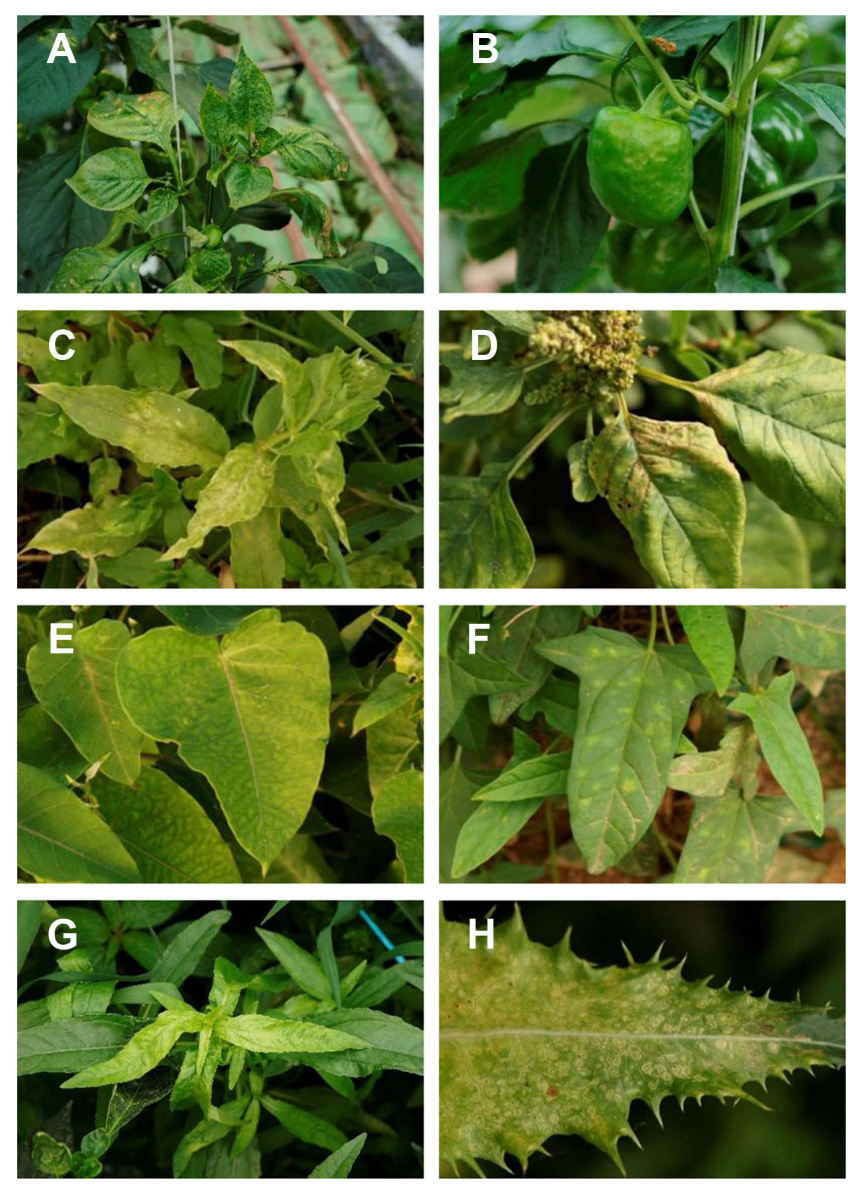

Fig. 2. Tomato spotted wilt virus (TSWV)-infected pepper plants and weeds collected for TSWV detection. (A) Leaf symptoms of TSWV-infected pepper plants. (B) Fruit symptoms of TSWVinfected sweet pepper plants. (C) Stellaria aquatica. (D) Amaranthus lividus. (E) Metaplexis japonica. (F) Calystegia sepium. (G) Eclipta alba. (H) Sonchus asper.

\section{Results and Discussion}

Species identification of collected samples. For 4 years, to identify natural hosts of crops and weeds that can be infected with TSWV, a total of 1,104 samples was collected from weeds (830 samples) and crops (274 samples) from five areas in Korea where TSWV has occurred (Table 1, Fig. 2). Because weeds have various life cycles (summer annual, winter annual, and perennial), it is hard to find many different kinds of weeds if sampling is conducted at a certain time only, so sample collections were done repeatedly in the different seasons. In addition, we sampled in the open fields, heated greenhouses, and non-heated greenhouses as the weed species that can be identified can vary depending on heating during winter. Collected samples were confirmed as belonging to 144 species ( 34 crops and 
Table 2. Infection rate of Tomato spotted wilt virus (TSWV) in crops

\begin{tabular}{|c|c|c|c|c|c|}
\hline \multirow{2}{*}{ Family } & \multicolumn{2}{|r|}{ Species } & \multicolumn{2}{|c|}{ No. of samples } & \multirow{2}{*}{ Infectivity (\%) } \\
\hline & Common name & Scientific name & Tested & Detected & \\
\hline \multirow[t]{2}{*}{ Apiaceae } & Carrot & Daucus carota & 1 & 0 & 0 \\
\hline & Dropwort & Oenanthe javanica & 12 & 2 & 16.7 \\
\hline \multirow[t]{3}{*}{ Asteraceae } & Chrysanthemum & Chrysanthemum morifolium & 21 & 4 & 19 \\
\hline & Crown daisy & Chrysanthemum coronarium & 2 & 2 & 100 \\
\hline & Lettuce & Lactuca sativa & 38 & 2 & 5.3 \\
\hline \multirow[t]{2}{*}{ Brassicaceae } & Chinese cabbage & Brassica campestris & 22 & 17 & 77.3 \\
\hline & Chinese radish & Raphanus sativus & 4 & 1 & 25 \\
\hline Campanulaceae & Bellflower root & Platycodon grandiflorum & 1 & 1 & 100 \\
\hline Chenopodiaceae & Spinach & Spinacia oleracea & 38 & 2 & 5.3 \\
\hline Convolvulaceae & Sweet potato & Ipomoea batatas & 5 & 2 & 40 \\
\hline \multirow[t]{3}{*}{ Cucurbitaceae } & Cucumber & Cucumis sativus & 9 & 3 & 33.3 \\
\hline & Oriental melon & Cucumis melo & 1 & 1 & 100 \\
\hline & Pumpkin & Cucurbita moschata & 7 & 0 & 0 \\
\hline \multirow[t]{6}{*}{ Fabaceae } & Cassia seed & Cassia tora & 2 & 0 & 0 \\
\hline & Cow pea & Vigna sinensis & 1 & 0 & 0 \\
\hline & Mung bean & Phaseolus radiatus & 1 & 0 & 0 \\
\hline & Pea & Pisum sativum & 2 & 2 & 100 \\
\hline & Peanut & Arachis hypogaea & 18 & 5 & 27.8 \\
\hline & Red bean & Phaseolus angularis & 4 & 2 & 50 \\
\hline Lamiaceae & Perilla seed & Perilla frutescens & 2 & 0 & 0 \\
\hline \multirow[t]{4}{*}{ Liliaceae } & Chinese Chive & Allium tuberosum & 5 & 0 & 0 \\
\hline & Shallot & Allium ascalonicum & 24 & 6 & 25 \\
\hline & Spring onion & Allium fistulosum & 5 & 0 & 0 \\
\hline & Wild chive & Allium monanthum & 2 & 0 & 0 \\
\hline Malvaceae & Curled mallow & Malva verticillata & 7 & 2 & 28.6 \\
\hline Moraceae & Mulberry tree & Morus alba & 8 & 1 & 12.5 \\
\hline Pedaliacae & Sesame & Sesamum indicum & 3 & 1 & 33.3 \\
\hline Ranunculaceae & Peony root & Paeonia lactiflora & 1 & 0 & 0 \\
\hline Rosaceae & Strawberry & Fragaria ananassa & 1 & 0 & 0 \\
\hline \multirow[t]{5}{*}{ Solanaceae } & Eggplant & Solanum melongena & 4 & 3 & 75 \\
\hline & Hot pepper & Capsicum annuum & 12 & 6 & 50 \\
\hline & Potato & Solanum tuberosum & 4 & 1 & 25 \\
\hline & Sweet pepper & Capsicum annuum & 6 & 6 & 100 \\
\hline & Tomato & Solanum lycopersicum & 1 & 1 & 100 \\
\hline Total & & & 274 & 73 & - \\
\hline
\end{tabular}

110 weeds) (Tables 1-3, Fig. 2).

Crop hosts. Among crops, plants that belong to the family Solanaceae including tomato, eggplant, and sweet pepper showed high infection rates (75-100\%) (Table 2). In the family Liliaceae, on the other hand, infection was observed only in shallot (Allium $\times$ proliferum). According to our observation in Yesan, shallot was cultivated in a non-heated greenhouse during winter as a perennial crop and was confirmed as an important host for propagation of west- ern flower thrips ( $F$. occidentalis). Thus, TSWV-infected shallot is a natural host for TSWV overwintering and propagation of the insect vector. In the family Fabaceae, three species (pea, peanut, and red bean) were confirmed as natural hosts in some places collected from an open field in Yeonggwang near many chrysanthemum cultivating greenhouses. From those farms, TSWV was also detected from chrysanthemum (19\%), and large colonies of western flower thrips were observed. Based on this result, the TSWV insect vector (western flower thrips), which cannot 
overwinter in open fields (Brødsgaard, 1993), could directly damage the crops in the open field the next spring after overwintering in Chrysanthemum greenhouses. Tomato, eggplant (S. melongena), lettuce (Lactuca sativa), and crown daisy (Glebionis coronaria) were infected as seedling stages of the crops in nurseries with TSWV-infected hot pepper plants in Seosan.

Our results show that cooperation of thrips controls at neighboring farms is very important for effective TSWV control. In particular, the occurrence of the thrips in crops other than pepper, known as the most important host of TSWV, can be overlooked, but it is important because it can cause the spread of the thrips. In Korea, especially when farming scale is small, many kinds of crops are mixed and grown in other fields. As our results show, not only solanaceous crops but also beans, cucurbits, sesame, shallot, and curled mallow can be natural hosts of TSWV in South Korea. Since these are commonly grown crops in Korea, even if the pepper or tomato farmers manage thrips, it is very likely that viruliferous thrips including the western flower thrips ( $F$. occidentalis) will continuously inflow from neighboring farms they are growing. This is also one of the reasons why TSWV problems continue to occur in Korea.
Weed hosts. Table 3 shows infection rates of TSWV in weeds. Among the weeds collected in areas of TSWV occurrence (110 species), 42 species in 22 families were identified as TSWV-infected. Asteraceae, Brassicaceae, and Caryophyllaceae families had the largest numbers of infected species (6 species each). According to life cycle analyses of TSWV weed hosts, 18 species were confirmed as winter annual $(42.9 \%), 30.9 \%$ (13 species) were summer annual, and $26.2 \%$ (11 species) were perennial (Table 3, Fig. 3). Among the weeds analyzed from numerous $(>20)$ samples, most samples of summer annual Eclipta alba (Fig. $2 \mathrm{G})$ showed TSWV infection (95.6\%), and half of winter annual Stellaria media (55\%) and perennial S. aquatica (54.5\%) (Fig. 2C) samples were confirmed as TSWV infected. A larger number of winter annual weeds were confirmed as many of those species overwintered in heated greenhouses in TSWV occurrence areas. These results suggest that winter annual weeds play important roles in overwintering of TSWV. From our previous study on overwintering of Tomato yellow leaf curl virus (TYLCV), it has been shown that $S$. aquatica can act as a viral source to newly introduced insect vectors in the next cultivation after overwintering in the non-heated greenhouse (Kil et al., 2015). We did not confirm overwintering of TSWV in wintering $S$. aquatica plants by time-course follow-up and arti-

\begin{tabular}{ll}
\multicolumn{1}{l}{$\begin{array}{l}\text { Summer annual weeds } \\
\text { Family }\end{array}$} \\
\hline Amaranthaceae & \multicolumn{1}{c}{ Species } \\
\cline { 2 - 2 } & Celosia cristata \\
\hline Asclepiadaceae & Metaplexis japonica \\
\hline Asteraceae & Eclipta alba \\
\hline Caryophyllaceae & Dianthus chinensis \\
\cline { 2 - 2 } & Melandryum firmum \\
\hline Chenopodiaceae & Chenopodium ficifolium \\
\hline Commelinaceae & Commelina communis \\
\hline Euphorbiaceae & Acalypha australis \\
\hline Malvaceae & Althaea rosea \\
\hline Polygonaceae & Persicaria longiseta \\
\hline Scrophulariaceae & Mazus pumilus \\
\hline Solanaceae & Solanum nigrum \\
\hline
\end{tabular}

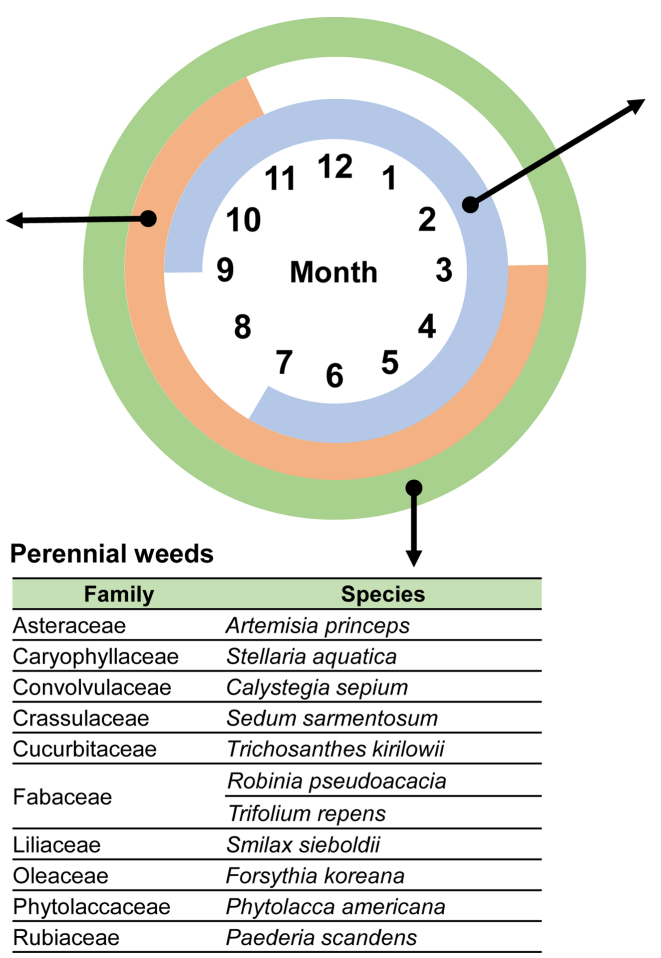

\begin{tabular}{ll}
\multicolumn{1}{c}{ Winter annual weeds } \\
\hline Family & \multicolumn{1}{c}{ Species } \\
\hline Asteraceae & $\frac{\text { Conyza canadensis }}{\text { Hemistepta lyrata }}$ \\
\hline & $\frac{\text { Sonchus asper }}{\text { Youngia japonica }}$ \\
\hline Brassicaceae & $\frac{\text { Brassica juncea }}{\text { Cardamine fallax }}$ \\
\cline { 2 - 2 } & $\frac{\text { Cepidium virginicum }}{\text { Rorippa indica }}$ \\
\hline Rorippa palustris \\
\hline Caryophyllaceae & $\frac{\text { Cerastium glomeratum }}{\text { Stellaria alsine }}$ \\
\hline Fabaceae & Stellaria media \\
\hline Lamiaceae & Vicia hirsuta \\
\hline Poaceae & Lamium amplexicaule \\
\hline Rubiaceae & Poa annua \\
\hline & Galium spurium \\
\hline
\end{tabular}

Fig. 3. Schematic diagram of Tomato spotted wilt virus (TSWV) life cycles in natural weed hosts. The three different circles indicate the three different life cycles (summer annual, winter annual, and perennial) of weed hosts introduced in this study. 
Table 3. Infection rate of Tomato spotted wilt virus (TSWV) in detected weeds

\begin{tabular}{|c|c|c|c|c|c|}
\hline \multirow{2}{*}{ Family } & \multirow{2}{*}{ Species } & \multirow{2}{*}{ Life cycle } & \multicolumn{2}{|c|}{ No. of samples } & \multirow{2}{*}{ Infectivity (\%) } \\
\hline & & & Tested & Detected & \\
\hline \multirow[t]{2}{*}{ Amaranthaceae } & Amaranthus lividus & SA & 88 & 18 & 20.5 \\
\hline & Celosia cristata & SA & 1 & 1 & 100 \\
\hline Asclepiadoideae & Metaplexis japonica & SA & 4 & 1 & 25 \\
\hline \multirow[t]{6}{*}{ Asteraceae } & Artemisia princeps & $\mathrm{P}$ & 50 & 17 & 34 \\
\hline & Eclipta alba & SA & 45 & 43 & 95.6 \\
\hline & Conyza canadensis & WA & 7 & 2 & 28.6 \\
\hline & Hemistepta lyrata & WA & 14 & 6 & 42.9 \\
\hline & Sonchus asper & WA & 17 & 11 & 64.7 \\
\hline & Youngia japonica & WA & 12 & 4 & 33.3 \\
\hline \multirow[t]{6}{*}{ Brassicaceae } & Brassica juncea & WA & 2 & 1 & 50 \\
\hline & Cardamine fallax & WA & 4 & 2 & 50 \\
\hline & Cardamine flexuosa & WA & 29 & 2 & 6.9 \\
\hline & Lepidium virginicum & WA & 1 & 1 & 100 \\
\hline & Rorippa indica & WA & 1 & 1 & 100 \\
\hline & Rorippa palustris & WA & 3 & 1 & 33.3 \\
\hline \multirow[t]{6}{*}{ Caryophyllaceae } & Cerastium glomeratum & WA & 8 & 2 & 25 \\
\hline & Dianthus chinensis & SA & 2 & 2 & 100 \\
\hline & Melandryum firmum & SA & 1 & 1 & 100 \\
\hline & Stellaria alsine & WA & 2 & 2 & 100 \\
\hline & Stellaria aquatica & $\mathrm{P}$ & 22 & 12 & 54.5 \\
\hline & Stellaria media & WA & 69 & 33 & 55 \\
\hline Chenopodiaceae & Chenopodium ficifolium & SA & 2 & 1 & 50 \\
\hline Commelinoideae & Commelina communis & SA & 18 & 6 & 33.3 \\
\hline Convolvulaceae & Calystegia sepium & $\mathrm{P}$ & 25 & 5 & 20 \\
\hline Crassulaceae & Sedum sarmentosum & $\mathrm{P}$ & 1 & 1 & 100 \\
\hline Cucurbitaceae & Trichosanthes kirilowii & $\mathrm{P}$ & 1 & 1 & 100 \\
\hline Euphorbiaceae & Acalypha australis & SA & 17 & 1 & 5.9 \\
\hline \multirow[t]{4}{*}{ Fabaceae } & Robinia pseudoacacia & $\mathrm{P}$ & 3 & 1 & 33.3 \\
\hline & Trifolium repens & $\mathrm{P}$ & 1 & 1 & 100 \\
\hline & Vicia amoena & WA & 1 & 1 & 100 \\
\hline & Vicia hirsuta & WA & 1 & 1 & 100 \\
\hline Lamiaceae & Lamium amplexicaule & WA & 2 & 2 & 100 \\
\hline Liliaceae & Smilax sieboldii & $\mathrm{P}$ & 1 & 1 & 100 \\
\hline Malvaceae & Althaea rosea & SA & 1 & 1 & 100 \\
\hline Oleaceae & Forsythia koreana & $\mathrm{P}$ & 3 & 2 & 66.7 \\
\hline Phytolaccaceae & Phytolacca americana & $\mathrm{P}$ & 60 & 16 & 26.7 \\
\hline Poaceae & Pоа аппиа & WA & 21 & 1 & 4.8 \\
\hline Polygonaceae & Persicaria longiseta & SA & 5 & 1 & 20 \\
\hline \multirow[t]{2}{*}{ Rubiaceae } & Galium spurium & WA & 12 & 8 & 66.7 \\
\hline & Paederia scandens & $\mathrm{P}$ & 4 & 3 & 75 \\
\hline Scrophulariaceae & Mazus pumilus & SA & 15 & 9 & 60 \\
\hline Solanaceae & Solanum nigrum & SA & 6 & 1 & 16.7 \\
\hline Total & & & 582 & 227 & - \\
\hline
\end{tabular}

SA, summer annual; P, perennial; WA, winter annual. 


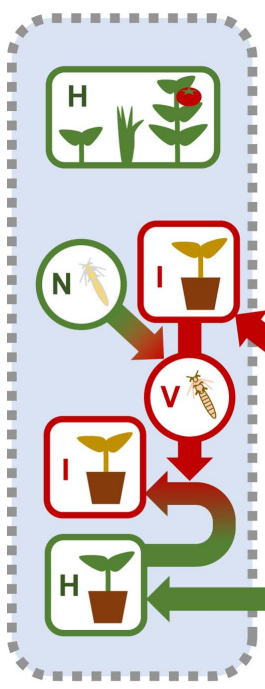

Greenhouse

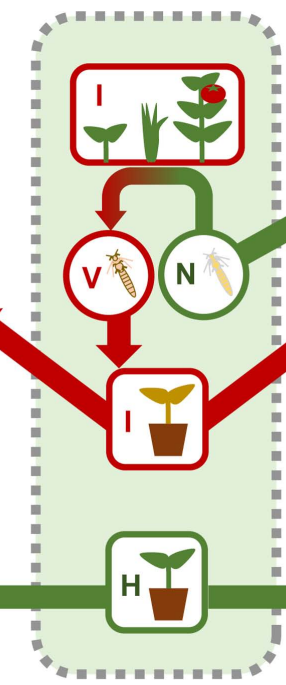

Nursery

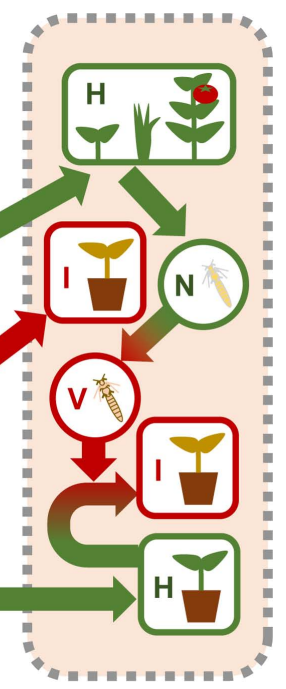

Open field

Fig. 4. Schematic diagram of Tomato spotted wilt virus (TSWV) disease cycles with thrips in a nursery for seedlings and greenhouse and open field for cultivating pepper plants. $\mathrm{H}$, healthy plants; I, infected plants; N, non-viruliferous thrips; and V, viruliferous thrips.

ficial experiments shown in the previous study on TYLCV, but it can be inferred that $S$. aquatica plants infected with TSWV play a similar role in overwintering and spread. $S$. media showed the highest infectivity among winter annual weeds, is the dominant species in greenhouses in the winter season, and had a vital role as a reservoir host for TSWV and a main host for western flower thrips. Perennial weeds including Artemisia princeps, S. aquatica, Calystegia sepium (Fig. 2F), and Phytolacca americana are common in cultivation areas in Korea, so it is likely that they can act as green bridges for TSWV.

Epidemiological aspects of TSWV infection in crops and weeds in Korea. TSWV occurs repeatedly through complex interactions between main host plants, other crop and weed hosts, and the insect vector thrips in Korea (Fig. 4). In hot pepper cultivating farms and nurseries, TSWV occurrence is common in Korea. The western flower thrips has spread to all areas of Korea. As shown in the above results, weeds growing in a cultivation area and other crops grown in the same or neighboring greenhouses also can be infected with TSWV and weeds act as intermediate hosts. In a nursery for hot pepper seedlings in spring, TSWV infection was detected from Cetastium glomeratum, $S$. aquatica, S. media, Lamium amplexicaule, and Galium spurium, which are winter annual or perennial weeds. If healthy plants are moved to an open field or greenhouse for cultivation, some viruliferous insect vector can infect

them, creating additional inoculum for another vector. To overcome this cycle, control of insect vectors and weeds is necessary, and selection of TSWV-resistant cultivars can reduce economic damage. However, there have been a few reports for TSWV isolates that overcome $T s w$ genemediated resistance in pepper (Boiteux and de Ávila, 1994; Jiang et al., 2017; Riley et al., 2011).

TSWV has been a long-standing problem in over 100 countries, and its host range is the largest (Cho et al., 1986, 1987; Parrella et al., 2003). In Korea, TSWV has been indigenous as a representative plant virus that continuously damages pepper cultivation, and it is damaging not only peppers but also cultivation of tomatoes, potatoes and chrysanthemums. In addition to the known hosts, new hosts are also being reported in Korea. $H$. japonicas, one of weeds that are easily observed in farms, was reported as TSWVinfected (Yoon et al., 2018a). Soybean (Glycine max) cultivated commonly and famous ornamental plant $P$. $o b$ tusifolia introduced from Taiwan and China have also been identified as TSWV recently (Yoon et al., 2018b, 2019). These reports mean that TSWV host range analyses for the commonly cultivated or newly introduced crops, and the weeds found on farms should be done continuously to update lists of TSWV hosts, which can be helpful to design strategy for effective controls. This study was conducted to investigate crop and weed hosts of TSWV from areas near hot pepper cultivating farms in Korea and 23 crop species and 42 weed species were confirmed as TSWV-infected in fields. Our updated list of natural hosts from this study can be used for TSWV control.

\section{Acknowledgments}

This study was supported by the Grant from Rural Development Administration (number PJ01011302).

\section{References}

Adkins, S. 2000. Tomato spotted wilt virus - positive steps towards negative success. Mol. Plant Pathol. 1:151-157.

Best, R. J. 1968. Tomato spotted wilt virus. Adv. Virus Res. 13:65146.

Boiteux, L. S. and de Ávila, A. C. 1994. Inheritance of a resistance specific to tomato spotted wilt tospovirus in Capsicum chinense 'PI 159236'. Euphytica 75:139-142.

Brittlebank, C. C. 1919. Tomato diseases. J. Agric. Victoria 17:213-235.

Brødsgaard, H. F. 1993. Cold hardiness and tolerance to submergence in water in Frankliniella occidentalis (Thysanoptera: Thripidae). Environ. Entomol. 22:647-653.

Chatzivassiliou, E. K., Boubourakas, I., Drossos, E., Elefthero- 
horinos, I., Jenser, G., Peters, D. and Katis, N. I. 2001. Weeds in greenhouses and tobacco fields are differentially infected by Tomato spotted wilt virus and infested by its vector species. Plant Dis. 85:40-46.

Cho, J. J., Mau, R. F. L., Gonsalves, D. and Mitchell, W. C. 1986. Reservoir weed hosts of tomato spotted wilt virus. Plant Dis. 70:1014-1017.

Cho, J. J., Mau, R. F. L., Mitchell, W. C., Gonsalves, D. and Yudin, L. S. 1987. Research Extension Series; RES-078. Host list of plants susceptible to Tomato spotted wilt virus (TSWV). University of Hawaii, Honolulu, HI, USA. 10 pp.

Choi, S.-K., Cho, I.-S., Choi, G.-S. and Yoon, J.-Y. 2014. First report of Tomato spotted wilt virus in Brugmansia suaveolens in Korea. Plant Dis. 98:1283.

Costa, A. S. 1941. Una molestia de virus de amendoim (Arachis hypogaea L.) A mancha anular. Biologico 7:249-251.

Fenner, F. 1976. The classification and nomenclature of viruses. Summary of results of meetings of the International Committee on Taxonomy of Viruses in Madrid, September 1975. J. Gen. Virol. 31:463-470.

German, T. L., Ullman, D. E. and Moyer, J. W. 1992. Tospoviruses: diagnosis, molecular biology, phylogeny, and vector relationships. Annu. Rev. Phytopathol. 30:315-348.

Jiang, L., Huang, Y., Sun, L., Wang, B., Zhu, M., Li, J., Huang, C., Liu, Y., Li, F., Liu, Y., Dong, J., Zhang, Z. and Tao, X. 2017. Occurrence and diversity of Tomato spotted wilt virus isolates breaking the $T s w$ resistance gene of Capsicum chinense in Yunnan, southwest China. Plant Pathol. 66:980-989.

Kil, E.-J., Byun, H.-S., Kim, S., Cho, S., Cho, S., Roh, K., Lee, K.-Y., Choi, H.-S., Kim, C.-S. and Lee, S. 2015. Tomato yellow leaf curl virus can overwinter in Stellaria aquatica, a winter-hardy TYLCV-reservoir weed. Plant Dis. 99:588-592.

Kim, J.-H., Choi, G.-S., Kim, J.-S. and Choi, J.-K. 2004. Characterization of Tomato spotted wilt virus from paprika in Korea. Plant Pathol. J. 20:297-301.

Kim, M., Kim, J. E., Kim, J., Kwak, H. R., Choi, H. S., Lee, H. J., Hong, S. S. and Kang, C. S. 2018. First report of Tomato spotted wilt virus in Hoya carnosa in Korea. Plant Dis. 102:1672.

Ko, S.-J., Kang, B.-R., Choi, D.-S., Kim, D.-I., Lee, G.-S., Kim, C.-S. and Choi, H.-S. 2013. Pattern of the occurrence of Tomato spotted wilt virus in Jeonnam province. Res. Plant Dis. 19:273-280 (in Korean).

Maes, P., Alkhovsky, S. V., Bào, Y., Beer, M., Birkhead, M., Briese, T., Buchmeier, M. J., Calisher, C. H., Charrel, R. N., Choi, I. R., Clegg, C. S., de la Torre, J. C., Delwart, E., DeRisi, J. L., Di Bello, P. L., Di Serio, F., Digiaro, M., Dolja, V. V., Drosten, C., Druciarek, T. Z., Du, J., Ebihara, H., Elbeaino, T., Gergerich, R. C., Gillis, A. N., Gonzalez, J.-P. J., Haenni, A.L., Hepojoki, J., Hetzel, U., Hồ, T., Hóng, N., Jain, R. K., Jansen van Vuren, P., Jin, Q., Jonson, M. G., Junglen, S., Keller, K. E., Kemp, A., Kipar, A., Kondov, N. O., Koonin, E. V., Kormelink, R., Korzyukov, Y., Krupovic, M., Lambert, A. J., Laney, A. G., LeBreton, M., Lukashevich, I. S., Marklewitz,
M., Markotter, W., Martelli, G. P., Martin, R. R., MielkeEhret, N., Mühlbach, H. P., Navarro, B., Ng, T. F. F., Nunes, M. R. T., Palacios, G., Pawęska, J. T., Peters, C. J., Plyusnin, A., Radoshitzky, S. R., Romanowski, V., Salmenperä, P., Salvato, M. S., Sanfaçon, H., Sasaya, T., Schmaljohn, C., Schneider, B. S., Shirako, Y., Siddell, S., Sironen, T. A., Stenglein, M. D., Storm, N., Sudini, H., Tesh, R. B., Tzanetakis, I. E., Uppala, M., Vapalahti, O., Vasilakis, N., Walker, P. J., Wáng, G., Wáng, L., Wáng, Y., Wèi, T., Wiley, M. R., Wolf, Y. I., Wolfe, N. D., Wú, Z., Xú, W., Yang, L., Yāng, Z., Yeh, S.-D., Zhāng, Y. Z., Zhèng, Y., Zhou, X., Zhū, C., Zirkel, F. and Kuhn, J. H. 2018. Taxonomy of the family Arenaviridae and the order Bunyavirales: update 2018. Arch. Virol. 163:2295-2310.

Murphy, F. A., Fauquet, C. M., Bishop, D. H. L., Ghabrial, S. A., Jarvis, A. W., Martelli, G. P., Mayo, M. A. and Summers, M. D. 1995. Archives of virology, supplement, Vol. 10. Virus taxonomy: classification and nomenclature of viruses. Sixth report of the International Committee on Taxonomy of Viruses. Springer-Verlag, Wien, Austria. 586 pp.

Pappu, H. R. 2008. Tomato spotted wilt virus. In: Encyclopedia of virology, 3rd ed., eds. by B. W. J. Mahy and M. H. V. Van Regenmortel, pp. 133-138. Elsevier Ltd., Oxford, UK.

Parrella, G., Gognalons, P., Gebre-Selassiè, K., Vovlas, C. and Marchoux, G. 2003. An update of the host range of Tomato spotted wilt virus. J. Plant Pathol. 85(4 Spec):227-264.

OEPP/EPPO. 1999. EPPO data sheets on quarantine pests. Tomato spotted wilt tospovirus. Bull. OEPP/EPPO Bull. 29:465472.

Riley, D. G., Joseph, S. V., Srinivasan, R. and Diffie, S. 2011. Thrips vectors of tospoviruses. J. Integr. Pest Manag. 2:I1-I10.

Sakimura, K. 1940. Evidence for the identity of the yellow-spot virus with the spotted-wilt virus: experiments with the vector, Thrips tabaci. Phytopathology 30:281-299.

Samuel, G. 1930. Investigations on 'spotted wilt' of tomatoes in Australia. Commonw. Aust. Counc. Sci. Ind. Res. Bull. 44:811.

Scholthof, K. B., Adkins, S., Czosnek, H., Palukaitis, P., Jacquot, E., Hohn, T., Hohn, B., Saunders, K., Candresse, T., Ahlquist, P., Hemenway, C. and Foster, G. D. 2011. Top 10 plant viruses in molecular plant pathology. Mol. Plant Pathol. 12:938954.

Sherwood, J. L., German, T. L., Moyer, J. W. and Ullman, D. E. 2009. Tomato spotted wilt virus. URL https://www.apsnet. org/edcenter/disandpath/viral/pdlessons/Pages/TomatoSpottedWilt.aspx [5 December 2019].

Smith, K. M. 1931. Studies on potato virus diseases VIII. On a ringspot virus affecting solanaceous plants. Ann. Appl. Biol. 18:1-15.

Sundaraj, S., Srinivasan, R., Culbreath, A. K., Riley, D. G. and Pappu, H. R. 2014. Host plant resistance against Tomato spotted wilt virus in peanut (Arachis hypogaea) and its impact on susceptibility to the virus, virus population genetics, and vector feeding behavior and survival. Phytopathology 104:202210. 
Yoon, J. Y., Choi, G. S. and Choi, S. K. 2017. First report of Tomato spotted wilt virus in Eustoma grandiflorum in Korea. Plant Dis. 101:515.

Yoon, J. Y., Choi, G. S., Jang, S. W., Park, S. H. and Choi, S.-K. 2018a. First report of Tomato spotted wilt virus in Humulus japonicus in Korea. Plant Dis. 102:690.
Yoon, J. Y., Choi, G. S., Kwon, S. J. and Cho, I. S. 2019. First report of Tomato spotted wilt virus infecting Peperomia obtusifolia in South Korea. Plant Dis. 103:593.

Yoon, Y. N., Jo, Y., Cho, W. K., Choi, H., Jang, Y., Lee, Y. H., Bae, J. Y. and Lee, B. C. 2018b. First report of Tomato spotted wilt virus infecting soybean in Korea. Plant Dis. 102:461. 